\title{
研究論文
}

\section{Zr-Cu-Ni-Al 系金属ガラスの塑性変形挙動に及ぼす貴金属添加の影響}

\author{
山崎 徹 ${ }^{1}$, 山田 昌弘 ${ }^{2}$, 藤田 和孝 ${ }^{3}$, 加藤 秀実 ${ }^{4}$, Do Hyang Kim ${ }^{5}$ \\ $1 *$ 兵庫県立大学大学院工学研究科材料・放射光工学専攻, $\bar{T} 671-2280$ 姫路市書写 2167 . \\ 2 兵庫県立大学大学院工学研究科, [(現) NTN 株 (株), $\bar{T} 550-0003$ 大阪市西区京町堀 1-3-17]. \\ ${ }^{3}$ 宇部工業高等専門学校機械工学科, ₹ 755-8555 宇部市常盤台 2-14-1. \\ ${ }^{4}$ 東北大学金属材料研究所, $\overline{7} 980-8577$ 仙台市青葉区片平 2-1-1. \\ ${ }^{5}$ 延世大学校工科大学材料工学科, ソウル $120-74$, 大韓民国.
}

\section{Effects of Noble Metal Additons on Plastic Deformation of Zr-Cu-Ni-Al Based Bulk Metallic Glasses}

\author{
Tohru YAMASAKI ${ }^{1}$, Masahiro YAMADA ${ }^{2}$, Kazutaka FUJITA ${ }^{3}$, Hidemi KATO ${ }^{4}$ and Do Hyang $\mathrm{KIM}^{5}$ \\ ${ }^{1 *}$ Department of Materials and Synchrotron Radiation Engineering, Graduate School of Engineering, \\ University of Hyogo, 2167 Shosha, Himeji 671-2280, Japan. \\ ${ }^{2}$ Graduate School of Engineering, University of Hyogo, Himeji 671-2280, Japan. \\ (Present Address: NTN Corporation, 1-3-17 kyomachibori, nishi-ku, Osaka 550-0003, Japan) \\ ${ }^{3}$ Department of Mechanical Engineering, National Institute of Technology, Ube College, 2-14-1 Tokiwa-dai, Ube 755-8555, Japan. \\ ${ }^{4}$ Institute for Materials Research, Tohoku University, 2-1-1 Katahira, Sendai 980-8577 Japan. \\ ${ }^{5}$ Department of Materials Science and Engineering, Yonsei University, Seoul 120-749, Korea.
}

Received December 22, 2015; Revised February 20, 2016; Accepted March 1, 2016

\begin{abstract}
$\mathrm{Zr}-\mathrm{Cu}-\mathrm{Ni}$-Al bulk metallic glasses (BMGs) have been limited in practical applications because of their low ductility under tensile and compressive testing conditions. This may be due to the formation of highly localized shear bands during plastic deformation. In this study, effects of $\mathrm{Pd}, \mathrm{Pt}, \mathrm{Au}$ and $\mathrm{Ag}$ additions on mechanical properties of $\mathrm{Zr}-\mathrm{Cu}-\mathrm{Ni}-\mathrm{Al} \mathrm{BMGs}$ have been examined. By the noble metal additions, precipitation of the icosahedral quasicrystal phase (I-phase) in the supercooled liquids was observed. Compression tests were carried out in these BMGs at an initial strain rate of $1 \times 10^{-4} \mathrm{~s}^{-1}$ at room temperature. Especially, in the case of the Au-addition, large plastic deformation was observed and many shear bands were also observed in wide region of the side-surface of the fractured specimens. This may be due to dynamic precipitations of nanocrystalline particles inside the shear bands during compressive deformation that prevent the propagations of the deformation shear bands.
\end{abstract}

\section{KEY WORDS}

$\mathrm{Zr-Cu}-\mathrm{Ni}$-Al alloy, bulk metallic glass, plastic deformation, effects of noble metals

\section{1 緒言}

$\mathrm{Zr}$ 基金属ガラスは, 高強度, 高靱性を有するが加工硬化能 がなく, 局所的なせん断帯変形により脆性的に破壊する ${ }^{1-3)}$.

これは，せん断带内部で温度上昇が生じて過冷却液体が生成 し，粘性流動を生じて変形応力が大きく低下するためと考え られている ${ }^{4-9)}$. 一方, $\mathrm{Zr}$ 基金属ガラスの塑性変形能に及ほ す合金組成依存性の影響については著者らの研究を含めてい くつかの報告があり, $\mathrm{Zr}$ 含有量の増加に伴い塑性変形能の 大きな改善効果が見出されている ${ }^{10-16)}$. 最近では， 65 at.\%以

* Corresponding author, E-mail: yamasaki@u-hyogo.ac.jp
上の $\mathrm{Zr}$ 含有率を有する $\mathrm{Zr}-\mathrm{Cu}-\mathrm{Ni}-\mathrm{Al}$ 系金属ガラスに, $\mathrm{Au}$ を わずかに添加した合金では，過冷却液体からの準結晶相（I 相）の析出が容易となり，圧縮抒よび引張時の塑性変形能 が大きく改善することを明らかとしている ${ }^{10}$. この原因とし て, せん断带の内部で動的に準結晶等のナノ結晶粒子が析出 し, 過冷却液体の粘性が上昇して, 変形応力の低下を抑制す るためと考えた。また，これら $\mathrm{Au}$ 添加した $\mathrm{Zr}-\mathrm{Cu}-\mathrm{Ni}-\mathrm{Al}$ 系 金属ガラスに強ひずみ加工処理を施すと，高密度にナノ結晶 粒子が分散されたナノ結晶/アモルファス複合組織の形成が 可能であることを示している ${ }^{15)}$.

本研究では， $\mathrm{Au}, \mathrm{Pd}, \mathrm{Pt}, \mathrm{Ag}$ 等の各種の貴金属を添加し 
た Zr-Cu-Ni-Al 系金属ガラスの圧縮塑性変形挙動をしらべる とともに, せん断带内部におけるナノ粒子の析出挙動と塑性 変形能との関連性について検討した。

\section{2 実験方法}

供試材の組成は $\mathrm{Zr}_{55} \mathrm{Cu}_{30} \mathrm{Ni}_{5} \mathrm{Al}_{10}, \mathrm{Zr}_{65} \mathrm{Cu}_{20} \mathrm{Ni}_{5} \mathrm{Al}_{10}$ （以下 $\mathrm{Zr} 55$, $\mathrm{Zr} 65$ と称す）および $\mathrm{Zr}_{65+\mathrm{X}} \mathrm{Cu}_{17-\mathrm{X}} \mathrm{Ni}_{5} \mathrm{Al}_{10}(\mathrm{Pd}, \mathrm{Pt}, \mathrm{Ag} \text { or } \mathrm{Au})_{3}, \quad(x=$ $0,1.5,3 \mathrm{at} \%$ ) (以下 $\mathrm{Zr} 65 \sim 68(\mathrm{Pd}, \mathrm{Pt}, \mathrm{Ag}$ or $\mathrm{Au}) 3$ と称す) とし た。各種組成となるよう原料を秤量し, 高純度 $\mathrm{Ar}$ 雲囲気中 のアーク溶解により母合金を作製した，それら母合金を，傾 角鋳造法により内径 $\phi 8 \mathrm{~mm}$ および $\phi 3.5 \mathrm{~mm}$, 長さ $\mathrm{L}=60 \mathrm{~mm}$ の円柱状の銅製金型を用いて急冷し，金属ガラス試料を作製 した.

各金属ガラス試料の構造は $\mathrm{X}$ 線回折測定（リガク社製 RINT2200V， 40 kV-20 mA，Cu-Ka 線）により確認した。 ガ ラス転移温度 $\left(T_{\mathrm{g}}\right)$ および結晶化開始温度 $\left(T_{\mathrm{x}}\right)$ は, 示差走 査熱量計（DSC，Perkin-Elmer 社製 DSC8500）により測定し た. 昇温速度は $40 \mathrm{~K} / \mathrm{min}$ および $400 \mathrm{~K} / \mathrm{min}$ とし, Ar 雾囲気 中で測定した。これら試料を用いて圧縮試験を常温にて実施 した．供試材は，as-cast材および $\left(T_{\mathrm{g}}-100\right) \mathrm{K}-5.4 \mathrm{ks}$ 熱処理 材とした. なお, 熱処理後も, 塑性変形中の応力低下が最も 少なかったZr66.5Au3 合金については, $\left(T_{\mathrm{g}}-50\right) \mathrm{K}-5.4 \mathrm{ks} の$ 熱処理材についても圧縮試験を行った。圧縮試験片は内径 \$3.5 mm の金型に鋳造した円柱状試料から，機械加工により 形状 $\phi 2 \mathrm{~mm} \times L 4 \mathrm{~mm}$ の試験片を切り出した。島津製作所社 製オートグラフ AG-ISにより，初期ひずみ速度 $1 \times 10^{-4} / \mathrm{s}$ で 圧縮試験を行った，装置治具の剛性は $65 \mathrm{kN} / \mathrm{mm}$ であり，ひ ずみ量はクロスヘッドの変位から治具の変形量を差し引き, 試験片初期高さで除して求めた。本方法によって得られた降 伏点でのひずみ量は，いずれも $2 \%$ 程度であった，圧縮試験 中の試験片の形状変化は, 高速度ビデオカメラ (Photron 社 製の FASTCAM-APX RS）を用いて，一画像当たりの撮影時 間 $1 / 60 \mathrm{~s}$ で計測した。

透過型電子顕微鏡（JEOL 社製 JEM-2100）を用いて，圧縮 試験後の主せん断帯付近の組織観察を行った。組織観察用試 料は, 主せん断帯に平行に破面を残すように研磨して作製し た. 試験片をせん断帯と平行にエメリー紙で研磨して削り 出した後, さらに液体窒素で冷却しながら Gatan 社製 PIPS Model-691 でArイオン研磨して作製した.

\section{3 実験 結果}

Fig. 1 に傾角鋳造法により作製したas-cast状態の Zr55, Zr65, Zr65 $68(\mathrm{Pd}, \mathrm{Pt}, \mathrm{Ag}$ or Au)3 合金の X 線回折測定結果 を示す.ここでは， $\phi 8 \mathrm{~mm}$ の円柱状銅製金型を用い，冷却 速度が比較的遅い条件下でも, 安定してバルク状アモルファ ス単相合金の作製が可能な合金組成を検討した。 アーク溶解 した合金液体を鋳造凝固させた後, 金型底面から $\mathrm{L}=30 \mathrm{~mm}$ のところで切り出し, その断面を用いてX 線回折測定を行っ た. 貴金属を添加するとアモルファス形成能は低下する傾向 にあったが，Zr含有量が 65.0 at.\% および 66.5 at.\%では，い

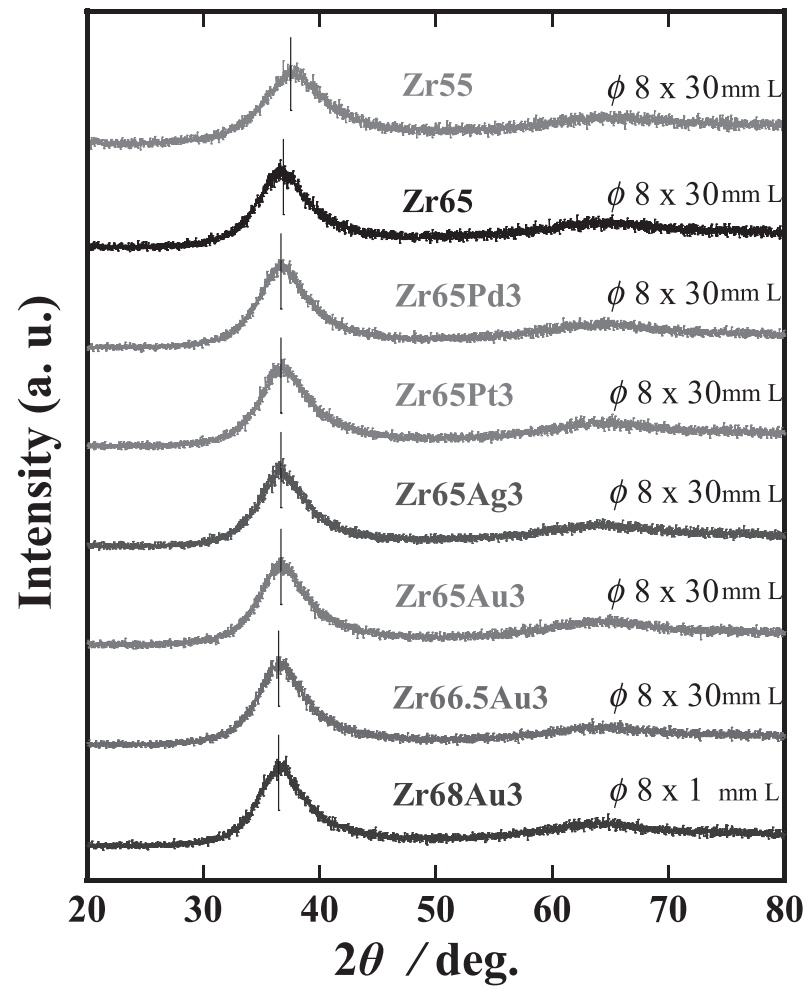

Fig. 1 X-ray diffraction patterns of the $\mathrm{Zr}_{55} \mathrm{Cu}_{30} \mathrm{Ni}_{5} \mathrm{Al}_{10}, \mathrm{Zr}_{65} \mathrm{Cu}_{20} \mathrm{Ni}_{5} \mathrm{Al}_{10}$ and $\mathrm{Zr}_{65+\mathrm{X}} \mathrm{Cu}_{17-\mathrm{X}} \mathrm{Ni}_{5} \mathrm{Al}_{10}(\mathrm{Pd}, \mathrm{Pt}, \mathrm{Ag} \text { or } \mathrm{Au})_{3},(x=0,1.5,3$ at $\%)$ BMGs.

ずれの合金もアモルファス相に特有のブロードな X 線回折 ピークを示し，バルク状の金属ガラスが作製できた。一方, $\mathrm{Zr}$ 含有量を 68 at.\%にまで増加させた Zr68Au3 合金では, 図 に示すように，金型底面から $\mathrm{L}=1 \mathrm{~mm}$ 付近まではブロード な X線回折ピークを有するアモルファス単相の試料が作製 できたが, $\mathrm{L}=1 \mathrm{~mm}$ 以上になると，主に $b c t-\mathrm{Zr}_{2} \mathrm{Cu}$ 相を中心 とする結晶相の析出が観察された.

Fig. 2 に, Fig. 1 で示した as-castの金属ガラス試料の DSC 測定結果を示す。昇温速度は $40 \mathrm{~K} / \mathrm{min}$ とした。いずれの合 金も, 明瞭なガラス転移とその後の結晶化発熱ピークが観 察された。 Zr55 およびZr65 合金では結晶化による1つの発 熱ピークが観察された，Zr55 合金では $T_{\mathrm{g}}$ は $685 \mathrm{~K} て ゙ ， \mathrm{~T}_{\mathrm{x}}$ は $775 \mathrm{~K}$ であり, $\Delta T_{\mathrm{x}}\left(=T_{\mathrm{x}}-T_{\mathrm{g}}\right)$ は $90 \mathrm{~K}$ であった. $\mathrm{Zr}$ 含有量を 増加させた $\mathrm{Zr} 65$ 合金では, $T_{\mathrm{g}}$ は $644 \mathrm{~K}$ と大きく低温側に移 動したが， $T_{\mathrm{x}}$ は $763 \mathrm{~K}$ と低温側への移動は比較的小さく，そ の結果, $\Delta T_{\mathrm{x}}=119 \mathrm{~K}$ となり過冷却液体温度領域は大きく拡 大した。

一方， $\mathrm{Zr}$ 含有量が 65 at.\% で，Pd，Pt，Ag，Auを 3 at.\% 添 加した合金では，結晶化による発熱ピークは 2 つ上観察さ れるようになり，過冷却液体温度領域は大きく縮小した。添 加する貴金属元素の種類により，最初に現れる第 1 発熱ピー ク温度は $713 \mathrm{~K} \sim 720 \mathrm{~K}$ の範囲で大きな差はなかったが，第 2 発熱ピークの開始温度は異なり, 特に $\mathrm{Ag}$ 添加材では第 1 お よび第 2 発熱ピークが大きく重なっていることがわかる.さ らにZr 含有量を増加させた Zr66.5Au3, Zr68Au3 合金では, 第 1 発熱ピークは低温側に大きく移動し, その結果として, 


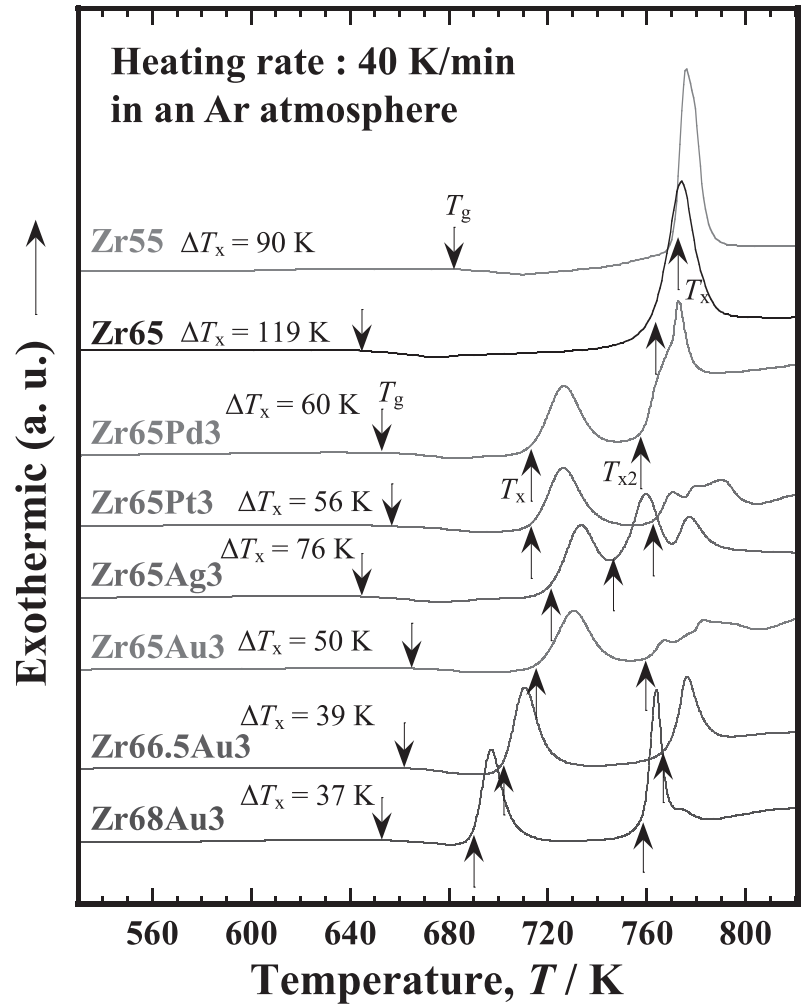

Fig. 2 DSC curves of the $\mathrm{Zr}_{55} \mathrm{Cu}_{30} \mathrm{Ni}_{5} \mathrm{Al}_{10}, \mathrm{Zr}_{65} \mathrm{Cu}_{20} \mathrm{Ni}_{5} \mathrm{Al}_{10}$ and $\mathrm{Zr}_{65+\mathrm{X}} \mathrm{Cu}_{17-\mathrm{X}} \mathrm{Ni}_{5} \mathrm{Al}_{10}(\mathrm{Pd}, \mathrm{Pt}, \mathrm{Ag} \text { or } \mathrm{Au})_{3},(x=0,1.5,3$ at $\%) \mathrm{BMGs}$ at a heating rate of $40 \mathrm{~K} / \mathrm{min}$ in an $\mathrm{Ar}$ atmosphere.

第 1 および第 2 発熱ピーク間の温度差は拡大し，両発熱ピー クの重なりは認められなくなる。

Fig. 3 に，各金属ガラス試料を Fig. 2の DSC 曲線の第 1 発 熱ピークの頂点温度までDSC 加熱炉内で昇温し，直ちに空 冷処理した後のX線回折測定結果を示す．図から明らかな ように, $\mathrm{Zr} 55$ 合金においては，主に $f c c-\mathrm{Zr}_{2} \mathrm{Ni}$ 相の析出が同 定された。一方, $\mathrm{Zr} 65$ 合金においては，主にbct- $\mathrm{Zr}_{2} \mathrm{Cu}$ 相と $f c c-\mathrm{Zr}_{2} \mathrm{Ni}$ 相の析出が同定された。 $\mathrm{Pd} ， \mathrm{Pt}$ および $\mathrm{Au}$ を添加し たZr65Pd3，Zr65Pt3，Zr65Au3，Zr66.5Au3，Zr68Au3 合金で は, いずれも準結晶相（I相）のみの析出が同定されたが, $\mathrm{Ag}$ を添加した $\mathrm{Zr} 65 \mathrm{Ag} 3$ 合金では, I 相と bct $-\mathrm{Zr}_{2} \mathrm{Cu}$ 相の 2 相 の析出が認められた．Fig. 2 の DSC 曲線と比較すると明らか なように，Pd，Ptおよび Au 添加材では第 1 発熱ピークと第

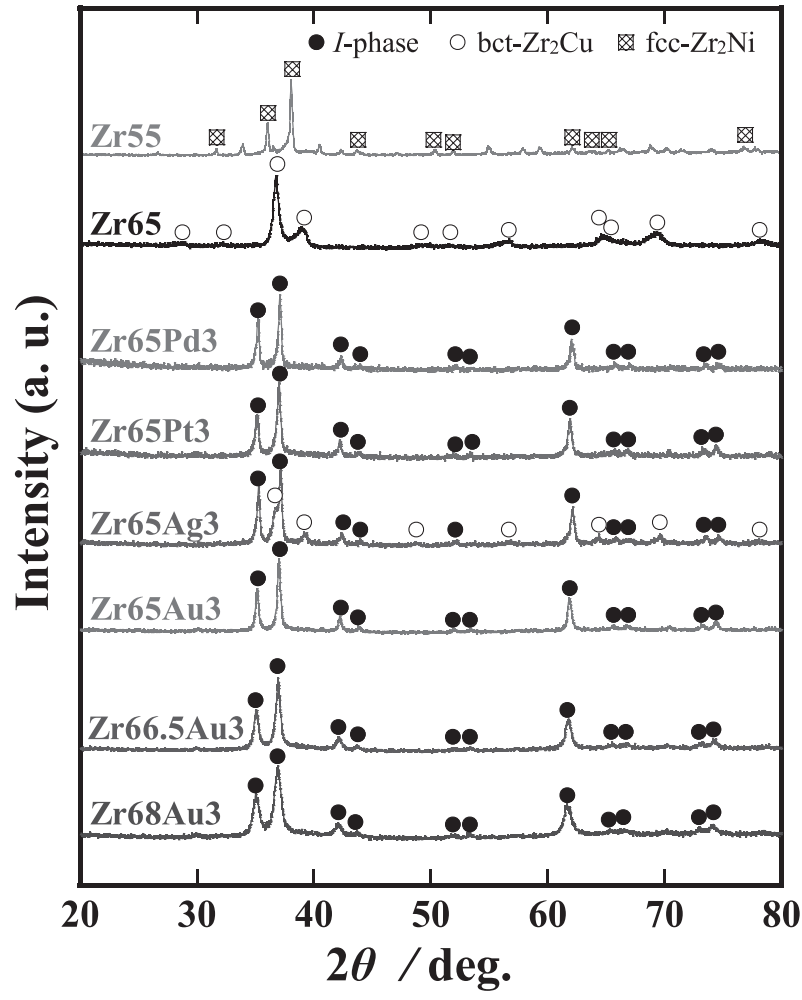

Fig. 3 X-ray diffraction patterns of the $\mathrm{Zr}_{55} \mathrm{Cu}_{30} \mathrm{Ni}_{5} \mathrm{Al}_{10}, \mathrm{Zr}_{65} \mathrm{Cu}_{20} \mathrm{Ni}_{5} \mathrm{Al}_{10}$ and $\mathrm{Zr}_{65+\mathrm{X}} \mathrm{Cu}_{17-\mathrm{X}} \mathrm{Ni}_{5} \mathrm{Al}_{10}(\mathrm{Pd}, \mathrm{Pt}, \mathrm{Ag} \text { or } \mathrm{Au})_{3},(x=0,1.5,3$ at $\%)$ BMGs after heating up to the first exothermic peak temperatures in the DSC curves at a heating rate of $40 \mathrm{~K} / \mathrm{min}$ in an Ar atmosphere.

2 発熱ピークとは分離しており, 第 1 発熱ピークの頂点温度 まで加熱を施してもI相のみが析出した．一方， Ag 添加材 では，第 1 発熱ピークと第 2 発熱ピークが重なって出現して いることから，I相の析出とともに第 2 発熱ピークに拈ける $b c t-\mathrm{Zr}_{2} \mathrm{Cu}$ 相の析出が認められた。 なお，いずれの貴金属添 加材においても, Fig. 2 に示した DSC 測定後の $820 \mathrm{~K}$ 付近ま で加熱した試料では, I相は消失し, $b c t-\mathrm{Zr}_{2} \mathrm{Cu}$ 相, $f c c-\mathrm{Zr}_{2} \mathrm{Ni}$ 相および $h c p-\mathrm{Zr}_{6} \mathrm{NiAl}_{2}$ 相が析出していた.

Fig. 4 に，I相を析出させた Zr65Pt3 金属ガラス合金の透過 電子顕微鏡観察結果を示す。観察には, DSC 加熱炉内で第 1 発熱ピークの頂点温度まで加熱した後, 直ちに空冷した試 料を用いた．Fig. 4 (a)に示すように, 約 $50 \mathrm{~nm}$ 程度のナノ準 結晶粒子が高密度に析出しており, 図中の電子線回折パター
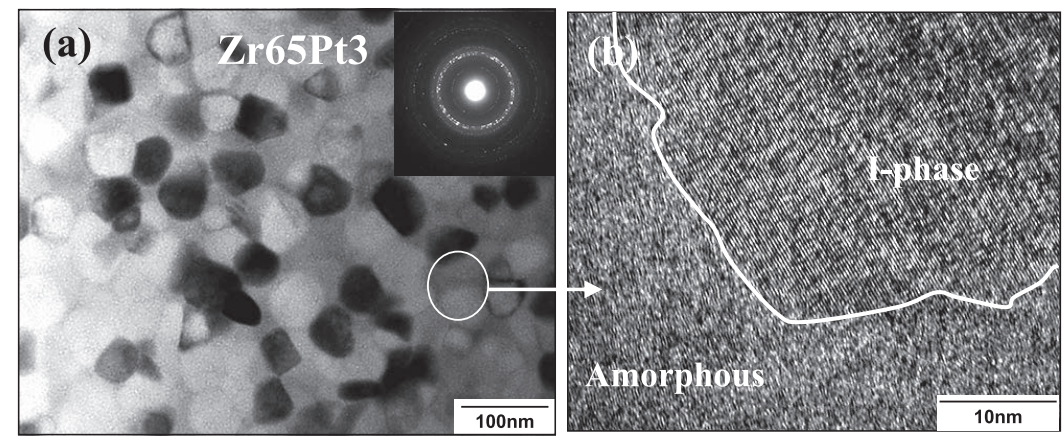

Fig. 4 TEM-images of the $\mathrm{Zr}_{65} \mathrm{Cu}_{17} \mathrm{Ni}_{5} \mathrm{Al}_{10} \mathrm{Pt}_{3} \mathrm{BMG}$ after heating up to the first ectothermic peak temperature in the DSC curve at a heating rate of $40 \mathrm{~K} / \mathrm{min}$ in an $\mathrm{Ar}$ atmosphere. 


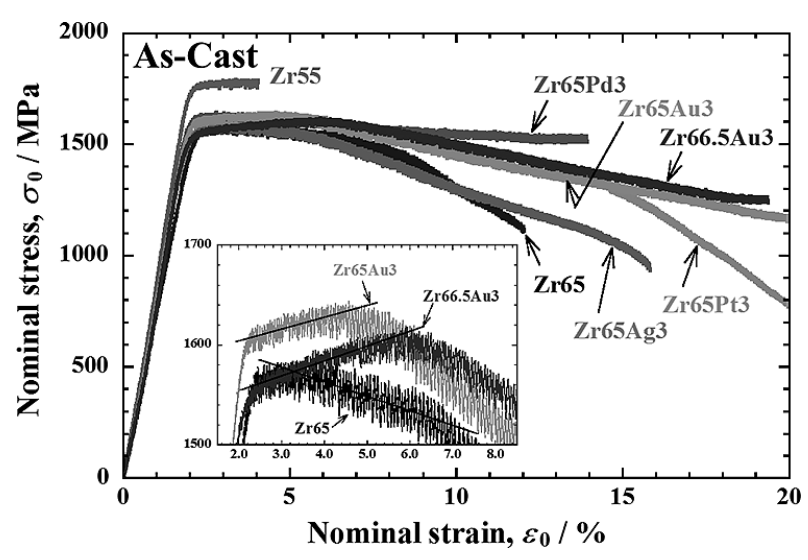

Fig. 5 Compressive stress-strain curves of the as-cast specimens of $\mathrm{Zr}_{55} \mathrm{Cu}_{30} \mathrm{Ni}_{5} \mathrm{Al}_{10}, \mathrm{Zr}_{65} \mathrm{Cu}_{20} \mathrm{Ni}_{5} \mathrm{Al}_{10}$ and $\mathrm{Zr}_{65+\mathrm{X}} \mathrm{Cu}_{17-\mathrm{X}} \mathrm{Ni}_{5} \mathrm{Al}_{10}$ (Pd, Pt, $\mathrm{Ag}$ or $\mathrm{Au})_{3},(x=0,1.5,3$ at\% $\mathrm{BMGs}$. Enlarged view of the strain range from $2 \%$ to $8 \%$ is also shown in this figure.

ンから，I相に対応する複数のシャープなデバイリングが観 察されるとともに, 若干のブロードな回折リングが残留し, I 相とアモルファス相の 2 相混合組織の特徴を示していた. Fig. 4 (b) にI相の析出粒子間部分に注目して, 高分解能像 （HRTEM 像）を観察した結果を示す，粒子間には格子縞は 観察されず，アモルファス相が残留し，I相とアモルファス 相の 2 相混合組織が形成されていることがわかる.

Fig. 5 に, Zr55, Zr65, Zr65 66.5 (Pd, Pt, Ag or Au)3 合金 の as-cast 材の圧縮試験結果を示す，Zr55 合金の降伏応力は 約 $1800 \mathrm{MPa}$ であり破断までの塑性変形ひずみは $2 \%$ 程度と 少ない。一方, Zr65 合金㧍よび Zr65〜66.5 (Pd, Pt, Ag or Au)3 合金においては，いずれも降伏応力は約 $1600 \mathrm{MPa}$ に低下 したが, 塑性変形量は飛躍的に増加した。特に, Zr65 Pt3, Zr65 Au3 およびZr66.5Au3 合金では, $\varepsilon=20 \%$ 付近まで試料 は破断分離することがなく試験を終了した。また，Zr65Au3 および Zr66.5Au3 合金では, 塑性変形初期から全圧縮ひずみ が $5 \%$ 付近に至るまで応力上昇を生じながら変形し，いわゆ る加工硬化現象が観察された，その後，塑性変形ひずみの増 加とともに緩やかに応力低下を生じた，Zr65，Zr65Pd3 おょ びZ $765 \mathrm{Ag} 3$ 合金では, 塑性変形初期から連続的に応力低下 を生じながら変形した。

Fig. 6 に, Zr65, Zr65 66.5 (Pd, Pt, Ag or Au)3 合金を, $\left(T_{\mathrm{g}}\right.$ 100) Kで $5.4 \mathrm{ks}$ 熱処理した後, 圧縮試験した結果を示す. Zr55 合金では熱处理後に激しい脆化が生じており塑性変形 は認めらなかったが, Zr65 合金抒よび貴金属添加合金におい ては，熱処理後にも関わらず，いずれの合金も大きな塑性変 形を示し, 熱処理による脆化が大きく抑制されていた. 従来,

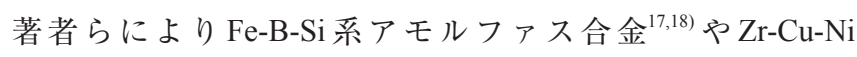
系金属ガラス ${ }^{10-15)} に$ に打いて，Fe-richやZr-rich 側のいわゆる 亜共晶組成の合金では熱処理時の脆化が抑制されることを報 告しており, Fig. 6 の結果は, これと同様の組成依存性を示 しているといえる.

$\mathrm{Au}$ を添加したZr65Au3 抢よびZr66.5Au3 合金では熱処理 後の脆化現象は観察されず, 塑性変形初期には加工硬化現象

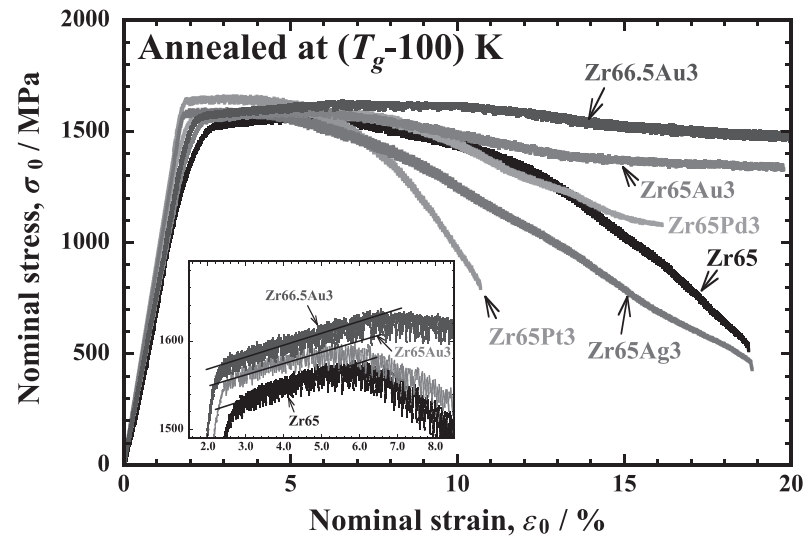

Fig. 6 Compressive stress-strain curves of the annealed BMG specimens at (Tg-100) $\mathrm{K}$ for $5.4 \mathrm{ks}$. Enlarged view of the strain range from $2 \%$ to $8 \%$ is also shown in this figure.

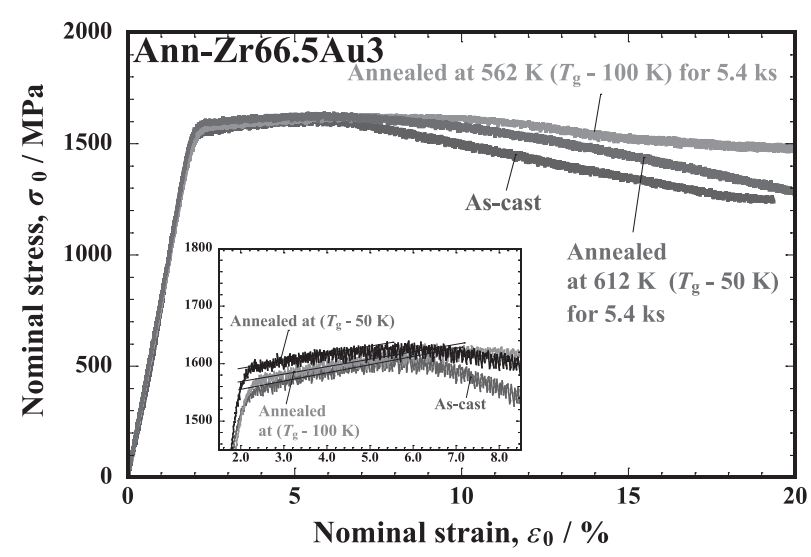

Fig. 7 Compressive stress-strain curves of the as-cast and annealed $\mathrm{Zr}_{66.5} \mathrm{Cu}_{15.5} \mathrm{Ni}_{5} \mathrm{Al}_{10} \mathrm{Au}_{3}$ BMG specimens at (Tg-100) $\mathrm{K}$ and $(\mathrm{Tg}-50)$ $\mathrm{K}$ for $5.4 \mathrm{ks}$. Enlarged view of the strain range from $2 \%$ to $8 \%$ is also shown in this figure.

が認められた，特に，Zr66.5Au3 合金においては，塑性変形 中の応力低下は as-cast 材に比べて大幅に低減されており， 熱処理によって材料強度の改善効果が認められる。一方, 熱 処理後の Zr65Pd3, Zr65Ag3, Zr65Pt3 合金では, 塑性変形初 期の加工硬化現象は認められず, 塑性変形の開始後の応力低 下は as-cast 材と比べて顕著となり，Zr65 合金と比較すると， 熱処理により脆化が生じているといえる.

Fig. 7 に, Zr66.5Au3 合金の as-cast材, $\left(T_{\mathrm{g}}-100\right) \mathrm{K}-5.4 \mathrm{ks}$ 抒 よび $\left(T_{\mathrm{g}}-50\right) \mathrm{K}-5.4 \mathrm{ks}$ 熱処理材の圧縮試験結果を示す．本合 金の場合には，熱処理温度を $\left(T_{\mathrm{g}}-50\right) \mathrm{K}$ まで上昇させても脆 化する傾向は認められない。降伏強度の僅かな上昇がみら れ，全圧縮ひずみが $5 \%$ 程度までの変形初期では加工硬化現 象が認められる。 その後の塑性ひずみの増加に伴う応力低下 の程度も少なく, むしろ熱处理による材料強度の改善効果が 認められる。

\section{4 考 察}

以上の結果から, $\mathrm{Zr}-\mathrm{Cu}-\mathrm{Ni}-\mathrm{Al}$ 系金属ガラスの圧縮塑性変 形能は，Zr含有量が 55 at.\%から 65 at.\%へ増加すると大き 
く改善すること,さらに，貴金属，特に Au を添加すること により熱処理後の脆化もほぼ完全に防止でき，塑性変形の初 期段階においては加工硬化現象が発現されることから，実用 材料として必要な材料強度特性が実現できることを示した。

この原因を検討するために，先ず，圧縮試験において，塑性 変形中に見られる主せん断带の形成挙動と応力低下現象との 関係について考察した。

4.1 主せん断帯の発生と構造変化

著者らはこれまでに, $\mathrm{Au}$ を添加した $\mathrm{Zr}-\mathrm{Cu}-\mathrm{Ni}-\mathrm{Al}$ 系金属が ラスは, 過冷却液体温度領域に扔いて準結晶相（I相）を析 出し，過冷却液体粘性を急速に上昇させることを示した。こ の結果から, 塑性変形中にせん断帯内部に過冷却液体が形成 されると, ナノ準結晶粒子の析出が生じて, 過冷却液体粘性 が上昇することにより，せん断帯の進展を抑制すると考えた

Fig. 8 に，高速度ビデオカメラを用いて，Zr65 合金の ascast 材 (Fig. 8 (a), (b)) と, Zr66.5Au3 合金の $\left(T_{\mathrm{g}}-50\right)$ K-5.4 ks 熱処理材 (Fig. 8 (c), (d)) の圧縮試験中の試験片の形状変化 を撮影した結果を示す，Zr65 合金では，Fig. 8 (a)に示すよ うに，全圧縮ひずみ $\varepsilon=3.8 \%$ で，既に試験片全体を貫通す る主せん断带の形成が認められる. Fig. 8 (b) の $\varepsilon=5.4 \%$ の 時では, 主せん断帯による試料表面段差のコントラストが 鮮明に観察され，主せん断帯に沿った変形が観察される。 Fig. 5 中に示した応力 - ひずみ線図の拡大図と比較すると,

\section{As-cast Zr65}
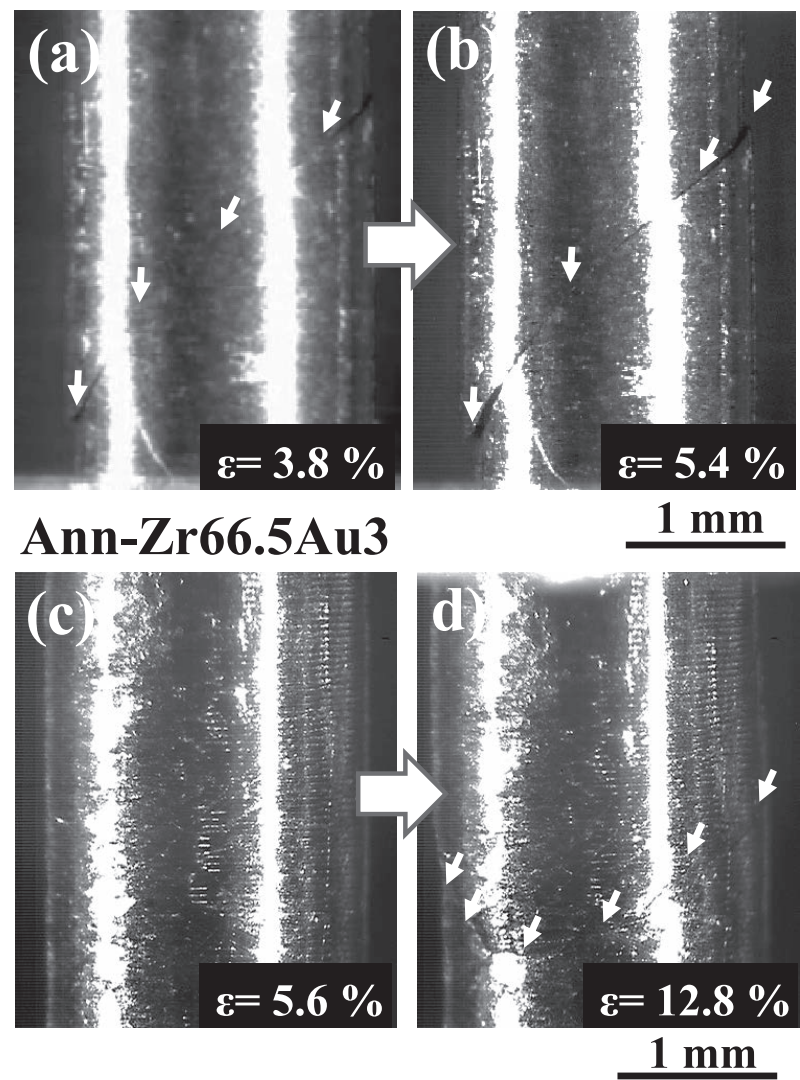

Fig. 8 High-speed video camera images during the compression tests at a strain rate of $1 \times 10^{-4} / \mathrm{s}$ for the as-cast $\mathrm{Zr}_{65} \mathrm{Cu}_{20} \mathrm{Ni}_{5} \mathrm{Al}_{10} \mathrm{BMG}$ (a), and the annealed $\mathrm{Zr}_{66.5} \mathrm{Cu}_{15.5} \mathrm{Ni}_{5} \mathrm{Al}_{10} \mathrm{Au}_{3} \mathrm{BMG}$ at (Tg-50) $\mathrm{K}$ for $5.4 \mathrm{ks}$ (b)
全圧縮ひずみが $\varepsilon=2.0 \%$ 付近で降伏後， $\varepsilon=3.0 \%$ 付近から 応力低下が開始しており，主せん断带の形成と応力低下現象 の開始が良く一致している.

一方, Zr66.5Au3 熱処理材では, Fig. 8 (c) の $\varepsilon=5.6 \%$ に示 すように，主せん断帯は未だ形成されておらず，全体として ほほ均一に変形していた。ささらに, Fig. 8 (d) に示すように, $\varepsilon=12.8 \%$ で主せん断带の形成が観察されるようになった. Fig. 6 の応力 - ひずみ線図の拡大図と比較すると, 本合金は, 全圧縮ひずみが $\varepsilon=2.0 \%$ 付近で降伏後， $\varepsilon=7.0 \%$ 付近まで 加工硬化を生じて応力上昇が認められ，その後，わずかに応 力低下を生じている。高速度ビデオカメラによる試験片形状 の変化では, $\varepsilon=7.0 \%$ 付近での主せん断帯の形成は, 観察 が困難であったが，全圧縮ひずみが $\varepsilon=10 \%$ 付近に達する付 近から徐々に主せん断带の形成が生じ，Fig. 8 (d) に示すよう に, $\varepsilon=12.8 \%$ で明瞭に観察されるようになる．以上の結果 から判断して, 両合金ともに, 塑性変形中に観察される応力 低下現象の開始は, 試験片全体を貫通する主せん断帯の形成 によるものと考えられ，Au添加により主せん断带の形成は 大きく抑制されているといえる.

Fig. 9 に, as-cast Zr65 材㧍よびZr66.5Au3 熱処理材の，圧 縮試験終了後の試験片側面を走査電子顕微鏡で観察した結果

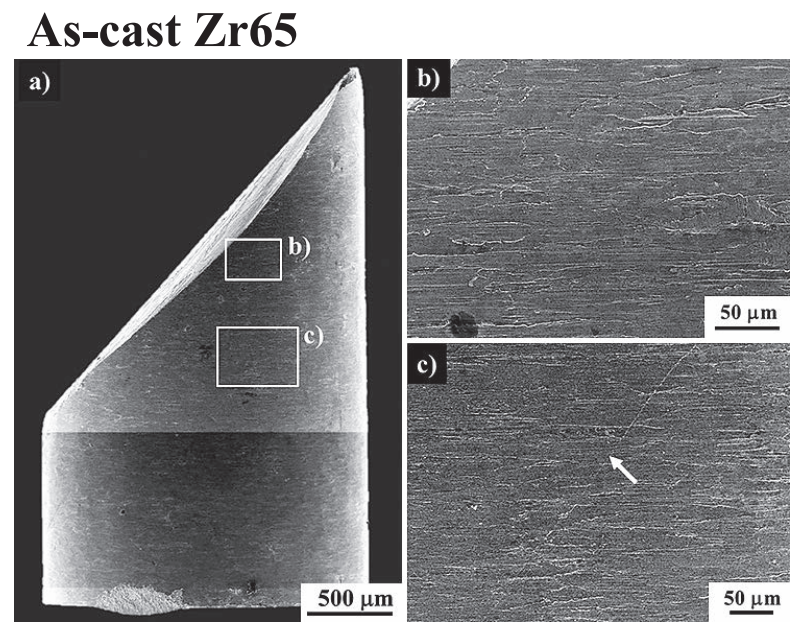

\section{Ann-Zr66.5Au3}

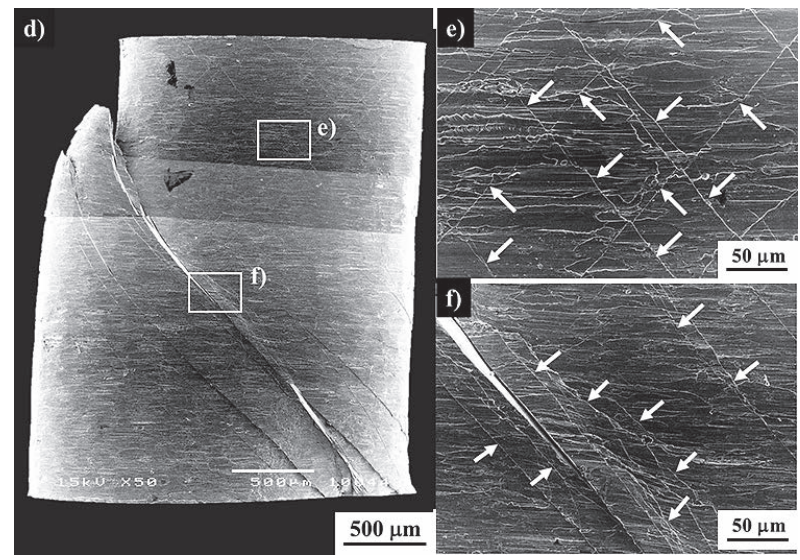

Fig. 9 SEM-micrographs of the as-cast $\mathrm{Zr}_{65} \mathrm{Cu}_{20} \mathrm{Ni}_{5} \mathrm{Al}_{10} \mathrm{BMG}$ (a) (c), and the annealed $\mathrm{Zr}_{6.5 .5} \mathrm{Cu}_{15.5} \mathrm{Ni}_{5} \mathrm{Al}_{10} \mathrm{Au}_{3} \mathrm{BMG}$ at $(\mathrm{Tg}-50) \mathrm{K}$ (d) (f) after compression tests at a strain rate of $1 \times 10^{-4} / \mathrm{s}$. 
を示す，両合金ともに，降伏応力は $1600 \mathrm{MPa}$ 程度で大きな 違いは認められないが, 圧縮試験後の試験片形状は大きく異 なる. Fig. 9 (a)〜(c) に示すように, as-cast Zr65 材では主せん 断帯に沿って試験片は破断分離し, 破断面近傍(b)および破 断面から離れた場所 (c)においても, 主せん断帯以外のせん 断帯の形成はほとんど認められなかった。一方, Fig. 9 (d)〜 (f) に示す Zr66.5Au3 熱処理材では，主せん断帯に沿って変 形しているものの, $\varepsilon=20 \%$ 付近まで圧縮変形しても試験片 の破断分離は生じていない.また，破断面近傍 (e) および破 断面から離れた場所 (f)においても, 多数のせん断帯の形成 が観察され，塑性変形は試験片全域にわたって生じている.

このような結果は, 最初のせん断帯が発生した時点で, 直ち に，そのせん断帯に沿った変形を停止させるような局所的加 工硬化の発現が必要であり, これがせん断帯内部に生ずる過 冷却液体中のナノ準結晶粒子の析出によるものと推定される.

Fig. 10 に, as-cast Zr65 材の HRTEM像を示す. 電子線回 折像においては，アモルファス相に特有のブロードな回折 パターンが観察された. Fig. 10 (a)に示すように, 全体に均 質なアモルファス構造の組織が観察され, Fig. 10 (b) の拡大 像においても，均質でランダムな原子配列構造が観察され る。図中の枠の範囲からの高速フーリエ変換像 (FFT) を観 察しても, 明確な規則性を観察することはできない. また, Fig. 11 に, as-cast Zr65 材を圧縮試験した後, 主せん断帯に 沿って薄膜化処理した試料の HRTEM 像を示す. Fig. 10 と同 様に, 電子線回折像はアモルファス相に特有のブロードな
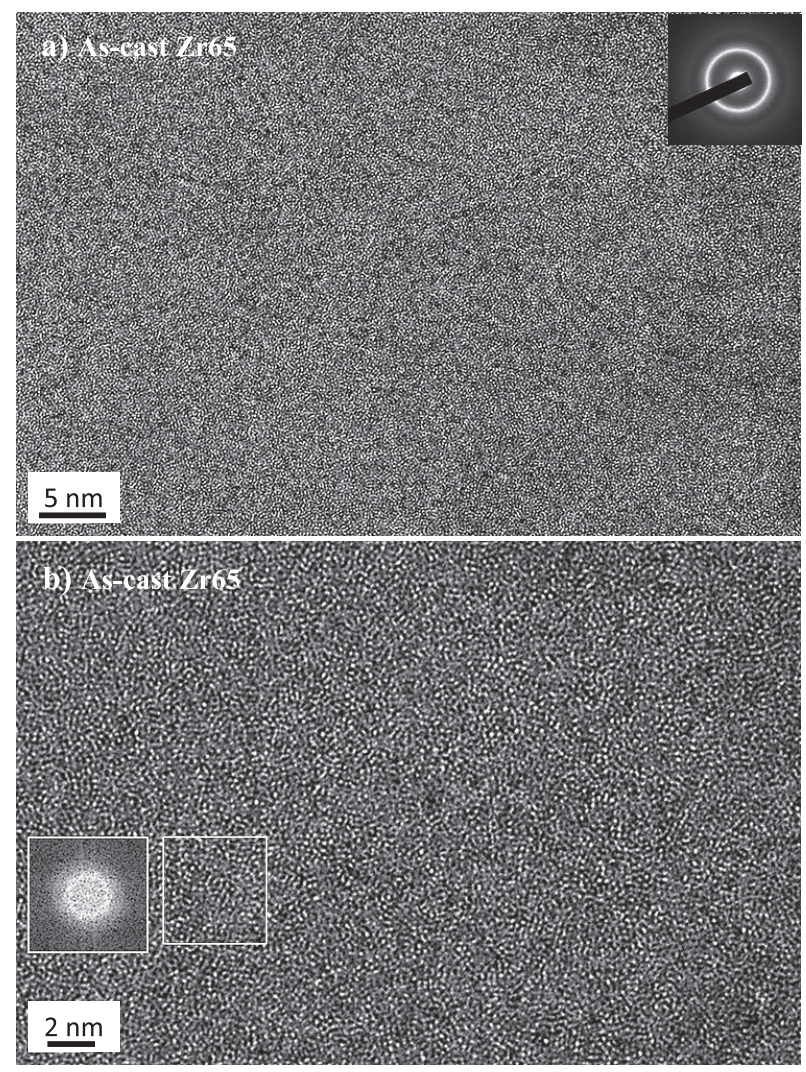

Fig. 10 HRTEM microstructures of as-cast $\mathrm{Zr}_{65} \mathrm{Cu}_{20} \mathrm{Ni}_{5} \mathrm{Al}_{10} \mathrm{BMG}$ specimen. FFT image is also shown in this figure.
回折パターンが観察された. Fig. 11 (a) および (b) に示すよう に, 全体に均質なアモルファス構造の組織が観察され, 圧縮 試験前の高分解像（Fig. 10 (a) および(b)）と比較しても, 特 に変化は認められない

Fig. 12 に, Zr66.5Au3 合金を $\left(T_{\mathrm{g}}-100\right) \mathrm{K}-5.4 \mathrm{ks}$ の条件で 熱処理した試料の HRTEM 像を示す. Fig. 12 (a)に示すよう に, $\phi 2 \sim 3 \mathrm{~nm}$ 程度のうすい周期的な明暗のコントラストが HRTEM 像全面に観察され, 熱処理による若干の組織変化が 生じたと考えられる。しかしながら，観察視野のほぼ全域か ら撮影した電子線回折像においては，アモルファス相に特有 のブロードな回折パターンが観察された．Fig. 12 (b) の拡大 像においても，ほほ均質なアモルファス構造を維持してお り, 図中の枠の範囲からの高速フーリエ変換像 (FFT) を観 察しても，明確な規則性を観察することはできなかった.

Fig. 13 に, Fig. 12 に示したZr66.5Au3 熱処理材を圧縮試験 した後，主せん断帯に沿って平行に薄膜化処理した試料の HRTEM 像を示す. Fig. 13 (a) 中に示すように, 電子線回折像 はアモルファス相に特有のブロードな回折パターンが観察さ れた. 圧縮試験前の HRTEM 像（Fig. 12 (a)）と比較すると, 組織全体に $\phi 2 \sim 3 \mathrm{~nm}$ 程度の周期的な明暗のコントラストがよ り鮮明に観察されるようになり, 構造変化が進行していると 考えられる. Fig. 13 (b)に, Fig. 13 (a)の HRTEM像の拡大像 を示す. 図中の枠からの高速フーリエ変換像 (FFT) から, ブロードな第 1 リング周辺に，矢印で示すように，ドットパ ターンが観察され，せん断帯の内部もしくはその近傍で，ア
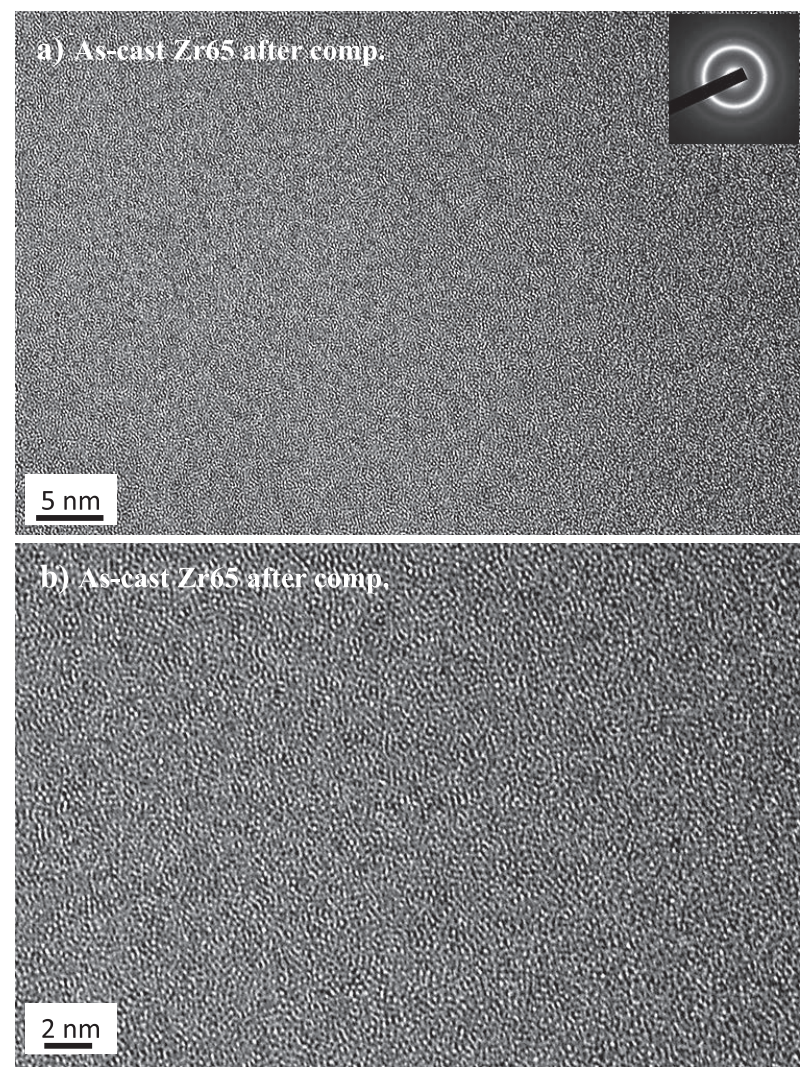

Fig. 11 HRTEM microstructures of the as-cast $\mathrm{Zr}_{65} \mathrm{Cu}_{20} \mathrm{Ni}_{5} \mathrm{Al}_{10}$ BMG specimen after compression test. 

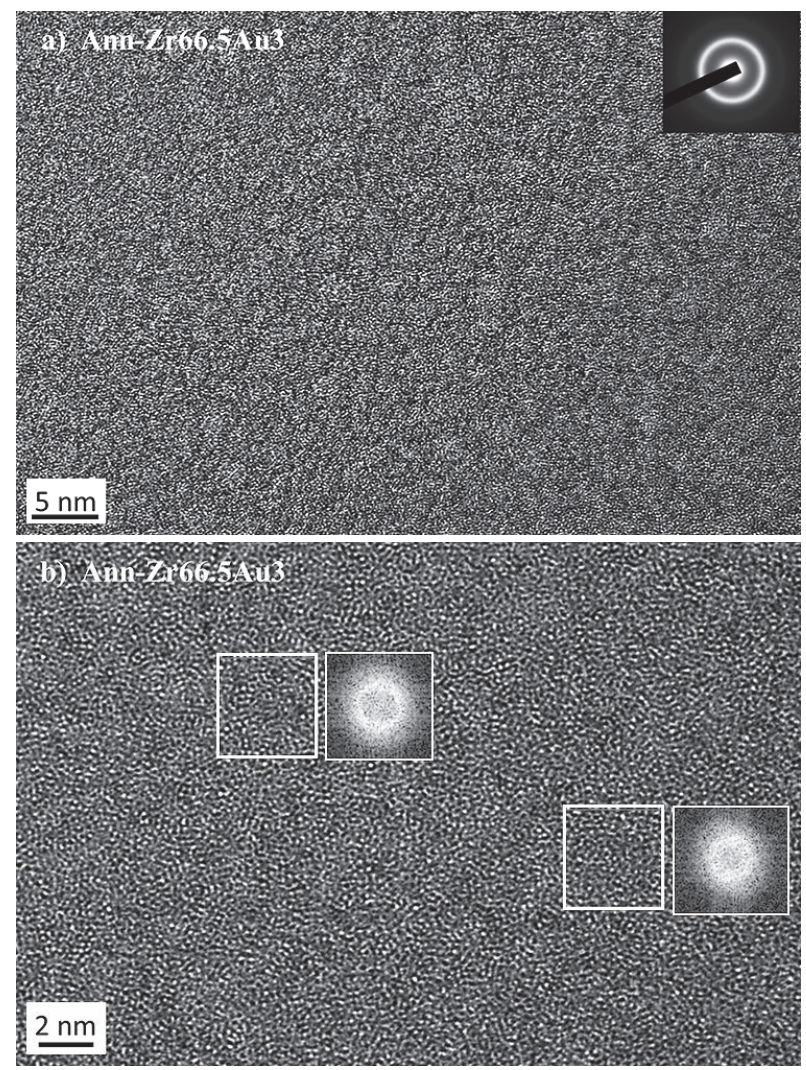

Fig. 12 HRTEM microstructures of the annealed $\mathrm{Zr}_{66.5} \mathrm{Cu}_{15.5} \mathrm{Ni}_{5} \mathrm{Al}_{10} \mathrm{Au}_{3}$ BMG specimen at (Tg-100) $\mathrm{K}$ for $5.4 \mathrm{ks}$. FFT images are also shown in this figure.

モルファス相の規則化が進行していると判断される.

Saida らは ${ }^{3)}$, 熱処理中にI相が析出する Zr-Cu-Ni-Pd系金 属ガラス合金を用いて, 引張変形中に発生したせん断帯内部 の透過電子顕微鏡観察を実施し，I相とは異なり $f c c-\mathrm{Zr}_{2} \mathrm{Ni}$ 相 の析出を報告している. Fig. 13 に示した本合金系の塑性変形 誘起のアモルファス合金中の構造変化に関しては，未だ，析 出相を同定できるものではないが, このような構造変化がせ ん断帯内部の過冷却液体粘性を増大させ, せん断帯の進展を 抑制しているものと考えられる.

$4.2 \mathrm{Au}, \mathrm{Pd}, \mathrm{Pt}, \mathrm{Ag}$ の添加効果の違いについて

上述のように，Zr-Cu-Ni-Al 系金属ガラスは，I相の析出を 誘発する $\mathrm{Au}$ を微量に添加することにより塑性変形性能が大 きく改善できることを示した。 しかしながら，同様にI相を 析出する Pd P Pt を添加しても塑性変形能の改善効果は限定 的であり, $\mathrm{Ag}$ 添加材については塑性変形能の低下をもたらす.

一般に，アモルファス相中で結晶化が開始すると激しい脆 化を生ずるが，I相は粗大な粒成長を生じにくく，I相をナ ノスケールに微細分散析出させることにより金属ガラスの塑 性加工性が大きく改善できることが報告されている ${ }^{19)}$.

Fig. 2 およびFig. 3 の結晶化時の DSC およびX線回折測定 結果に示したように, $\mathrm{Ag}$ 添加材では, I 相の析出と同時に $b c t-\mathrm{Zr}_{2} \mathrm{Cu}$ 相の析出も生ずることから, 塑性変形中の動的析 出過程で脆化を伴っていると推定される．圧縮試験結果にお いて, $\mathrm{Ag}$ 添加による塑性変形性能の改善効果が現れないの
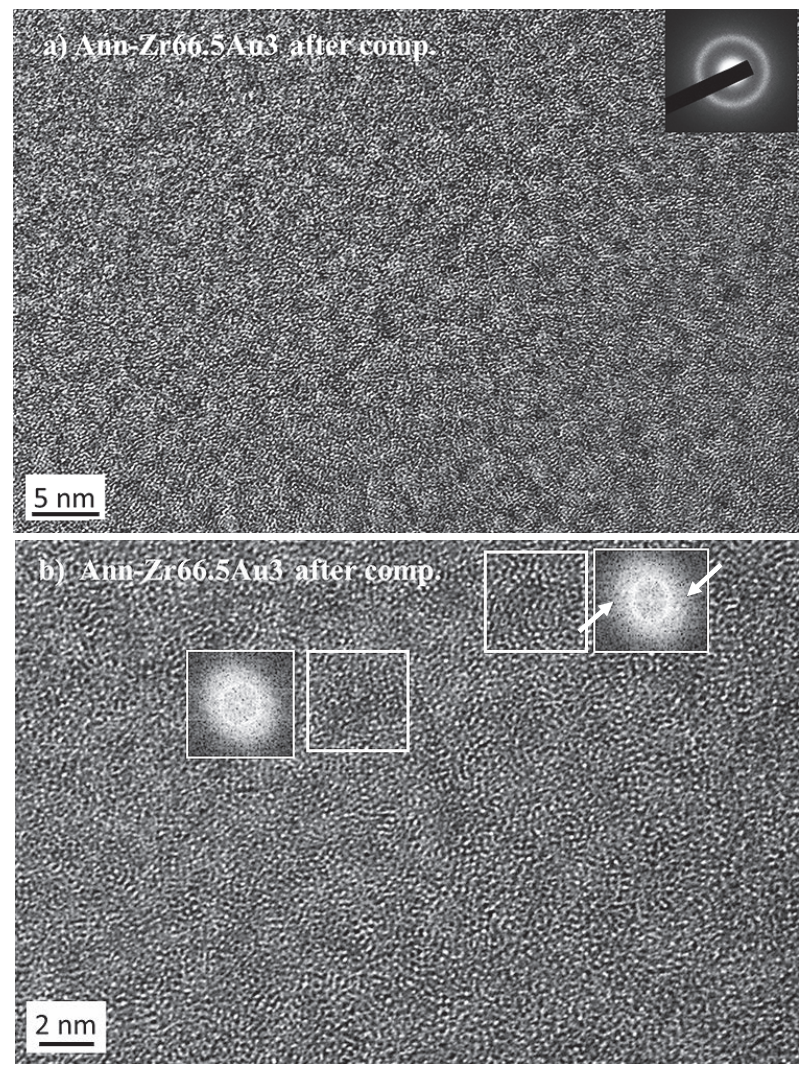

Fig. 13 HRTEM microstructures of the annealed and compressed $\mathrm{Zr}_{66.5} \mathrm{Cu}_{15.5} \mathrm{Ni}_{5} \mathrm{Al}_{10} \mathrm{Au}_{3} \mathrm{BMG}$ specimen at $(\mathrm{Tg}-100) \mathrm{K}$ for $5.4 \mathrm{ks}$. FFT imagse are also shown in this figure.

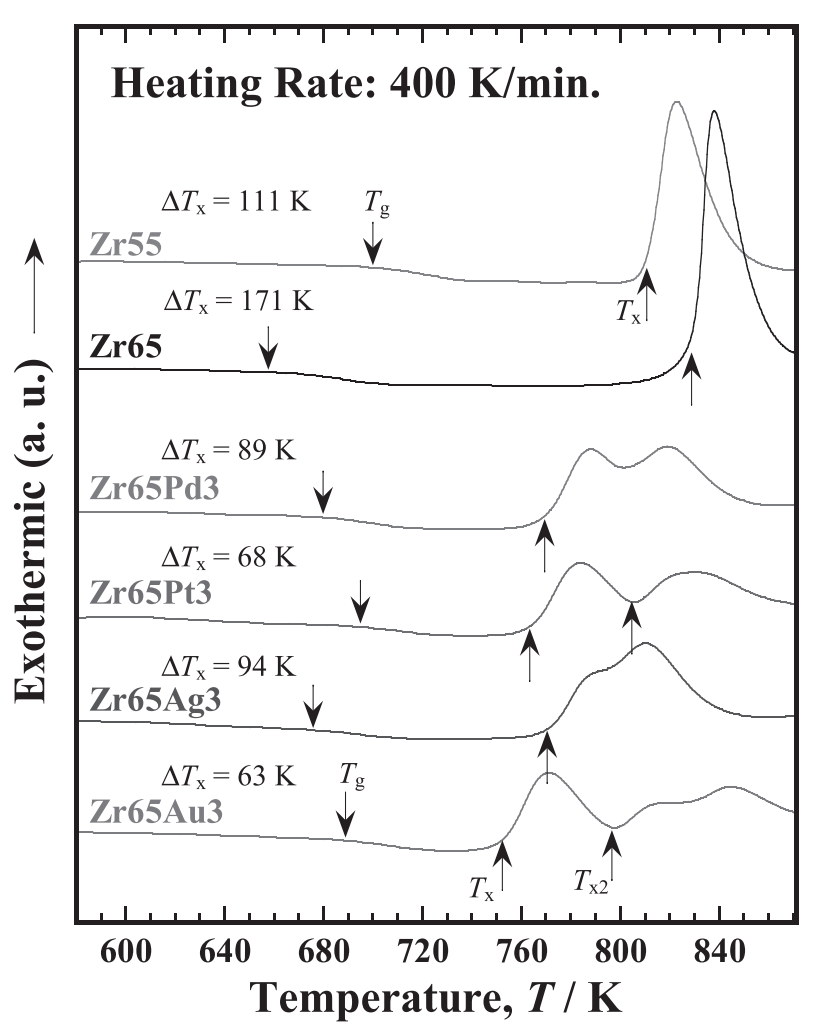

Fig. 14 DSC curves of the $\mathrm{Zr}_{55} \mathrm{Cu}_{30} \mathrm{Ni}_{5} \mathrm{Al}_{10}, \mathrm{Zr}_{65} \mathrm{Cu}_{20} \mathrm{Ni}_{5} \mathrm{Al}_{10}$ and $\mathrm{Zr}_{65+\mathrm{X}} \mathrm{Cu}_{17-\mathrm{X}} \mathrm{Ni}_{5} \mathrm{Al}_{10}(\mathrm{Pd}, \mathrm{Pt}, \mathrm{Ag} \text { or } \mathrm{Au})_{3},(x=0,1.5,3$ at $\%)$ BMGs at a heating rate of $400 \mathrm{~K} / \mathrm{min}$ in an $\mathrm{Ar}$ atmosphere. 
Table 1 DSC parameters of the $\mathrm{Zr}_{55} \mathrm{Cu}_{30} \mathrm{Ni}_{5} \mathrm{Al}_{10}, \mathrm{Zr}_{65} \mathrm{Cu}_{20} \mathrm{Ni}_{5} \mathrm{Al}_{10}$ and $\mathrm{Zr}_{65+\mathrm{X}} \mathrm{Cu}_{17-\mathrm{X}} \mathrm{Ni}_{5} \mathrm{Al}_{10}(\mathrm{Pd}, \mathrm{Pt}, \mathrm{Ag} \text { or Au })_{3}$, $(x=0,1.5,3$ at $\%)$ BMGs under the heating rates of $40 \mathrm{~K} / \mathrm{min}$ and $400 \mathrm{~K} / \mathrm{min}$ in an $\mathrm{Ar}$ atmosphere.

\begin{tabular}{ccccccccccccc}
\hline Sample & $T_{g-40 K}$ & & $T_{g-400 K}$ & $\delta T_{g}{ }^{*}$ & $T_{x-40 K}$ & & $T_{x-400 K}$ & $\delta T_{x}^{*}$ & $\Delta T_{x-40 K}{ }^{* *}$ & $\Delta T_{x-400 K}{ }^{* *}$ \\
\hline Zr55 & 685 & $\rightarrow$ & 699 & $\mathbf{1 4}$ & $\mathbf{7 7 5}$ & $\rightarrow$ & $\mathbf{8 1 0}$ & $\mathbf{3 5}$ & $\mathbf{9 0}$ & $\rightarrow$ & $\mathbf{1 1 1}$ \\
Zr65 & $\mathbf{6 4 4}$ & $\rightarrow$ & $\mathbf{6 5 2}$ & $\mathbf{8}$ & $\mathbf{7 6 3}$ & $\rightarrow$ & $\mathbf{8 2 3}$ & $\mathbf{6 0}$ & $\mathbf{1 1 9}$ & $\rightarrow$ & $\mathbf{1 7 1}$ \\
Zr65Pd3 & 653 & $\rightarrow$ & 680 & 27 & 713 & $\rightarrow$ & 769 & 56 & $\mathbf{6 0}$ & $\rightarrow$ & $\mathbf{8 9}$ \\
Zr65Pt3 & 657 & $\rightarrow$ & 695 & 38 & 713 & $\rightarrow$ & 763 & 50 & $\mathbf{5 6}$ & $\rightarrow$ & $\mathbf{6 8}$ \\
Zr65Ag3 & 645 & $\rightarrow$ & 675 & 31 & 721 & $\rightarrow$ & 769 & 49 & $\mathbf{7 6}$ & $\rightarrow$ & $\mathbf{9 4}$ \\
Zr65Au3 & 665 & $\rightarrow$ & 689 & 24 & 715 & $\rightarrow$ & 752 & 37 & $\mathbf{5 0}$ & $\rightarrow$ & $\mathbf{6 3}$ \\
\hline
\end{tabular}

* $\delta T_{g}=\left(T_{g-400 K^{-}} T_{g-40 K}\right), \delta T_{x}=\left(T_{x-400 K^{-}} T_{x-40 K}\right)$

** $\Delta T_{x-40 K}=\left(T_{x-40 K}-T_{g-40 K}\right), \Delta T_{x-400 K}=\left(T_{x-400 K}-T_{g-400 K}\right)$

は, この平衡相の同時析出が原因と考えられる. 一方, Pd, Pt およびAu添加材においては, Fig. 2 の DSC 曲線から明ら かなように，第1発熱ピークと第 2 発熱ピークは十分に分離 しており，Fig. 3 に示した第1発熱ピークまで加熱した試料 では，いずれの貴金属添加材もI相のみが析出していた？そ れにも関わらず，塑性変形性能に関する $\mathrm{Au}$ の添加効果は顕 著であるが, PdおよびPtの添加効果は限定的であり, 特に,

熱処理材に抢ける改善効果は認められなくなる.

実際の圧縮試験時には，せん断带内部で発生する過冷却液 体は，急速加熱状態で生成すると考えられるため，加熱速度 を上昇させて，第 1 発熱ピークと第 2 発熱ピークの重なり状 況を検討しなければならない。

Fig. 14 に, Zr55, Zr65, Zr65 (Pd, Pt, Ag or Au)3 合金の ascast 材を $400 \mathrm{~K} / \mathrm{min}$ の高速昇温条件下で DSC 測定した結果を 示す.また, Table 1 に昇温速度 $40 \mathrm{~K} / \mathrm{min}$ と $400 \mathrm{~K} / \mathrm{min}$ にお けるDSC 測定結果を比較して示した，昇温速度の上昇によ り $\mathrm{Zr} 55$ 合金の $f c c-\mathrm{Zr}_{2} \mathrm{Ni}$ 結晶化開始温度は高温側に $35 \mathrm{~K}$ シフ トしたが, $\mathrm{Zr} 65$ 合金の $b c t-\mathrm{Zr}_{2} \mathrm{Cu}$ の結晶化開始温度は高温側 に $60 \mathrm{~K}$ と大きく移動した。 一方, $\mathrm{T}_{\mathrm{g}}$ の高温側へのシフト温 度は両合金ともに小さく，その結果として $\Delta \mathrm{T}_{\mathrm{x}}$ が大きく拡大 した.

貴金属添加材である Zr65 (Pd, Pt, Ag)3 合金においては, I 相の結晶化開始温度は 49 56 K 大きく上昇したが，Zr65Au3 合金の上昇温度は $37 \mathrm{~K}$ と貴金属添加材の中では最も小さい. その結果, Zr65Ag3 合金では, 第 1 㧍よび第 2 発熱ピークは, ほほ全体的に重なってしまい, Zr65Pd3 合金抢よびZr65Pt3 合金においても，かなりの割合で重なりが認められる。した がって，これら合金に扔いては，せん断帯内部で動的ナノ粒 子の析出が生じた場合, I相の析出による塑性変形能の改善 効果と, $b c t-\mathrm{Zr}_{2} \mathrm{Cu}$ や $f c c-\mathrm{Zr}_{2} \mathrm{Ni}$ 相等の析出による脆化効果が 同時に生じていると考えられた.

一方，Zr65Au3 合金では，加熱速度の上昇による第 1 発熱 ピークの高温側へのピークシフトは比較的小さく, 昇温速度 $400 \mathrm{~K} / \mathrm{min}$ の条件下でも, 両発熱ピークは分離して観察され る. Fig. 2 の DSC 結果を比較してみると，Zr 含有量を増やし たZr66.5Au3 合金においては，両ピークの分離はさらに顕著 になると予想される．以上のことから，Au添加材において
は，せん断帯内部での動的ナノ粒子の析出時に，I相が優先 的に析出し, その他の結晶相の同時析出は困難となって脆化 が生じ難くなり, 塑性変形性能の改善が認められるものと考 えられる。

\section{5 結 言}

$\mathrm{Au}, \mathrm{Pd}, \mathrm{Pt}, \mathrm{Ag}$ を添加した Zr-Cu-Ni-Al系金属ガラスの塑 性変形挙動をしらべた。これらの貴金属を添加すると過冷却 液体温度領域からの準結晶相（I相）の析出が観察された. $\mathrm{Au}$ を添加した合金においては, 圧縮時の塑性変形性能が大 きく改善した。 この原因として, 塑性変形時に生ずる動的な アモルファス相の構造変化やナノ準結晶粒子の析出が, せん 断帯内部に生じた過冷却液体の粘度を上昇させ， せん断帯の 進行を抑制するためと考えられた，一方，塑性変形性能に及 ぼす Pd，Pt， Ag 添加による改善効果は限定的であった。こ の原因として, I 相の析出による塑性変形能の改善効果と, $b c t-\mathrm{Zr}_{2} \mathrm{Cu}$ や f $c c-\mathrm{Zr} \mathrm{r}_{2} \mathrm{Ni}$ 相等の析出による脆化効果が同時に生 じているためと考えられた。

\section{文献}

1) A. Inoue: "Stabilization of Metallic Supercooled Liquid and Bulk Amorphous Alloys", Acta Mater., 48 (2000) 279-306.

2) H. Kato, A. Inoue: "Synthesis and Mechanical Properties of Bulk Amorphous Zr-Al-Ni-Cu Alloys Containing ZrC Particles", Mater. Trans., 38 (1997) 793-800.

3) J. Saida, H.Kato, A. D. H. Setyawan, K. Yoshimi, A. Inoue: "Deformation Induced Nanoscale Dynamic Transformation Studies in Zr-Al-Ni-Pd and Zr-Al-Ni-Cu Bulk Metallic Glasses", Mater. Trans., 48 (2007) 1327-1335.

4) F. H. D. Torre, D. Klaumuänzer, R. Maab, J. F. Loäffler: "Stick-slip Behavior of Serrated Flow during Inhomogeneous Deformation of Bulk Metallic Glasses", Acta Mater., 58 (2010) 3742-3750.

5) S. X. Song, T. G. Nieh: "Direct Measurements of Shear Band Propagation in Metallic Glasses - An Overview", Intermetallics, 19 (2011) 1968-1977.

6) B. A. Sun, S. Pauly, J. Tan, M. Stoica, W. H. Wang, U. Kuähn, J. 
Eckert: "Serrated Flow and Stick-slip Deformation Dynamics in the Presence of Shear-band Interactions for a Zr-based Metallic Glass", Acta Mater., 60 (2012) 4160-4171.

7) H. S. Chen: Appl. "Stored Energy in a Cold - Rolled Metallic Glass”, Phys. Lett., 29 (1976) 328-330.

8) C. J. Gilbert, J. W. Ager, V. Schroeder, R. O. Ritchie: "Light Emission during Fracture of a $\mathrm{Zr}-\mathrm{Ti}-\mathrm{Ni}-\mathrm{Cu}-\mathrm{Be}$ Bulk Metallic Glass", Appl. Phys. Lett., 74 (1999) 3809-3811.

9) H. Tokunaga, J. Koyama, K. Fujita, Y. Yokoyama, T.Yamasaki, A. Inoue: "Mechanisms of Tensile Plastic Deformation in Zr70Ni16Cu6A18 Bulk Metallic Glass”, J. Japan Inst. Metals, 75 (2011) 569-574.

10) N. Yoshida, K. Fujita, Y. Yokoyama, H. Kimura, A. Inoue: "Effect of Zr Composition and Heat-Treatment on Fracture Toughness in Zr-Cu-Al Bulk Metallic Glass", J. Japan Inst. Metals, 71 (2007) 730-735.

11) Y. Yokoyama, T. Yamasaki, P. K. Liaw, A. Inoue: "Study of the Structural Relaxation-induced Embrittlement of Hypoeutectic $\mathrm{Zr}-\mathrm{Cu}-\mathrm{Al}$ Ternary Bulk Glassy Alloys", Acta Mater., 56 (2009) 6091-6108.

12) T. Yamasaki, M. Yamada, T. Mori, T. Kikuchi, Y. Yokoyama, A. Inoue, D. H. Kim: "Viscous Flow Behaviour of Supercooled Liquids and Mechanical Properties in Zr-Cu-Ni-Al Bulk Metallic Glasses”, Mater. Sci. Forum, 654-656 (2010) 10461049.

13) Y. Yokoyama, H. Tokunaga, A. R. Yavari, M. Yamada, T.
Yamasaki, K. Fujita, A. Inoue: "Viscous Flow in Sliding Shear Band Formed during Tensile Deformation of Hypoeutectic Zrbased Metallic Glass", Intermetallics, 19 (2011) 1683-1687.

14) Y. Yokoyama, M. Yamada, T. Mori, H. Tokunaga, T. Sato, T.Shima, M. Nishijima, K. Fujita, T. Yamasaki: "Solid Plasticity and Supercooled-liquid Thermo- plasticity of $\mathrm{Zr}-$ $\mathrm{Cu}$-enriched Hypoeutectic $\mathrm{Zr}-\mathrm{Cu}-\mathrm{Ni}-\mathrm{Al}$ Cast Glassy Alloys", Mater. Sci. Eng. A, 606 (2014) 74-80.

15) M. Yamada, R. Kamizato, T. Yamasaki, H. Adachi, K. Tsuchiya, Y. Yokoyama: "Nanocrystallization of Zr-Cu-Ni-AlAu Glassy Alloys during Severe Plastic Deformation", Mater. Sci. Eng., 63 (2014) 012167.

16) M. Yamada, T. Yamasaki, K. Fujita, Y. Yokoyama, D. H. Kim, "Effects of Au-Addition on Plastic Deformation Ability of ZrCu-Ni-Al Bulk Metallic Glasses”, J. Japan Inst. Met. Mater., 78 (2014), 449-458.

17) T. Yamasaki, Y. Ogino, T. Honda, Y. Amemiya, "Two-stage Temper Embrittlement of Amorphous Fe-B-Si Alloys and Structural Changes Examined by SR-Small Angle X-ray Scattering”, Scripta Metallurgica, 23 (1989) 1963-1968.

18) T. Yamasaki, K. Morishita, Y. Ogino, "Reversible Annealing Embrittlement of Amorphous Fe77B13Si10 Alloy", J. Japan Inst. Metals, 55 (1991) 383-389.

19) J. M. Park, H. J. Chang, K. H. Han, W. T. Kim, D. H. Kim, "Enhancement of plasticity in Ti-rich $\mathrm{Ti}-\mathrm{Zr}-\mathrm{Be}-\mathrm{Cu}-\mathrm{Ni}$ bulk metallic glasses", Scripta Materialia, 53 (2005) 1-6. 